\title{
Atomic Force Microscopy for Protein Detection and Their Physicochemical Characterization
}

\author{
Tatyana O. Pleshakova ${ }^{\mathbb{D}}$, Natalia S. Bukharina, Alexander I. Archakov and Yuri D. Ivanov * \\ Institute of Biomedical Chemistry, 10, Pogodinskaya St., 119121 Moscow, Russia; \\ t.pleshakova@gmail.com (T.O.P.); natalie_buharina@list.ru (N.S.B.); alexander.archakov@ibmc.msk.ru (A.I.A.) \\ * Correspondence: yurii.ivanov@rambler.ru
}

Received: 26 February 2018; Accepted: 5 April 2018; Published: 10 April 2018

\begin{abstract}
This review is focused on the atomic force microscopy (AFM) capabilities to study the properties of protein biomolecules and to detect the proteins in solution. The possibilities of application of a wide range of measuring techniques and modes for visualization of proteins, determination of their stoichiometric characteristics and physicochemical properties, are analyzed. Particular attention is paid to the use of AFM as a molecular detector for detection of proteins in solutions at low concentrations, and also for determination of functional properties of single biomolecules, including the activity of individual molecules of enzymes. Prospects for the development of AFM in combination with other methods for studying biomacromolecules are discussed.
\end{abstract}

Keywords: atomic force microscopy; protein fishing; protein characterization

\section{Introduction}

Study of intermolecular interactions and a quantitative characterization of the mechanisms of those interactions is of importance for profound understanding of different biological processes. In the past decades, novel techniques have been developed to manipulate and study single biomolecules [1,2]. The ability to monitor biological processes at this fundamental sensitivity level provides a better understanding of the molecular mechanisms. Averaging over an ensemble, distribution and fluctuation of molecular properties may be excluded from consideration at the single-molecule level. Thus, single-molecule experiments allow to study properties of heterogeneous systems compared to the standard ensemble methods [2]. Atomic force microscopy (AFM) occupies a prominent place in the range of techniques operating at the single-molecule level.

AFM was developed as a method for visualizing objects in 1986. In this method, three-dimensional (3D) topography images and structural details of the samples are obtained using cantilever which scans a surface [3]. It has become a powerful tool in the field of biomolecules and cells study due to its ability to scan a surface with (sub-) nanometer resolution in liquid [4]. Moreover, AFM does not require dye or fluorescent labels as optical microscopy. It allows for the imaging of biological objects from single molecules to the living cells as well as their manipulation. A lot of AFM modes have been developed to study biomolecules, and those modes are widely described in literature, but there is still a lot of research focused on improvements in AFM electronics, experiments with cantilever size [5], data interpretation and so on. This review is focused on the AFM capabilities to study protein biomolecules, their physicochemical properties, and perspectives to adapt AFM for biomedical detection of the low-abundance target proteins in solution. 


\section{Atomic Force Microscopy (AFM) Visualization of Proteins}

AFM has a great potential for biology applications with the broad range of visualization techniques (Figure 1, left column). Contact and dynamic modes have been the most popular ones over the years, and such modes as multiparametric and multi-frequency imaging, molecular recognition and high-speed AFM have been developed recently.

In a contact mode, AFM probe raster scans a sample surface at a constant setpoint. Constant force between probe and surface or constant height may be chosen as a setpoint. Resolution of the obtained topography image depends on a probe radius, sample roughness, its physical properties, and tracking accuracy of the feedback loop (performance).

A lot of biological objects such as animal cells [6,7], membrane surface of cell and membrane proteins [8,9], DNA and RNA [10-12], lipid films [13-15] were visualized by commercial AFMs. If objects have small height difference, for instance, proteins with height of $1 \mathrm{~nm}$ over the membrane surface, lateral and vertical resolutions of topography image may be less than $1 \mathrm{~nm}$ and $0.1 \mathrm{~nm}$, respectively [16-19]. Vertical resolution of AFM is about $0.1 \mathrm{~nm}$, which is close to the resolution of X-ray crystallography $[1,20]$. Thanks to high values of resolution and signal-to-noise ratio, it was possible to study the functionally dependent oligomeric state of water-soluble and membrane proteins [21].

The main disadvantage of contact mode is direct mechanical interaction between the probe and the surface. This could often lead to destruction of the sample surface during imaging [4,22]. Contact mode is widely used to specify properties of the solid substrates while to image the soft biological systems there should be an accurate adjustment of the force applied by cantilever. The force should be less than $100 \mathrm{pN}$ to avoid a nonreversible deformation of the sample [23].

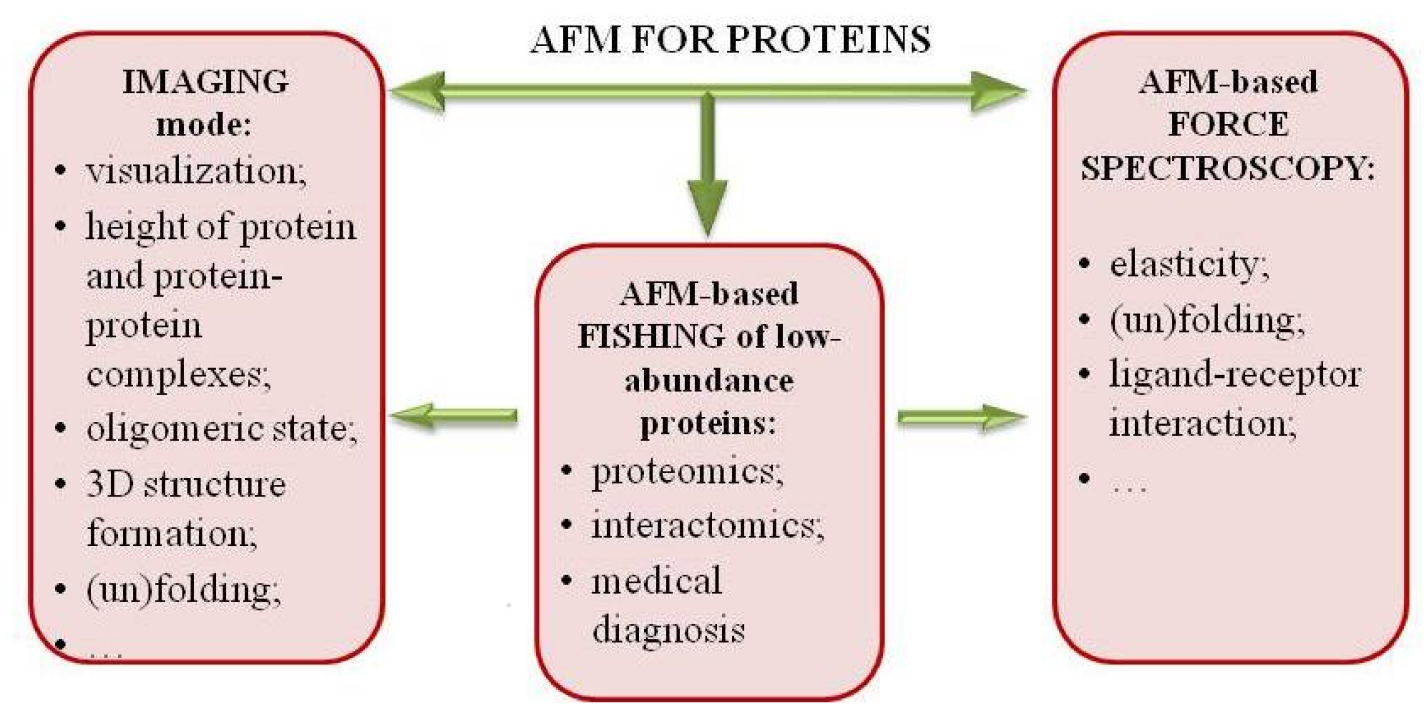

Figure 1. Application of atomic force microscopy (AFM) to study proteins. It includes three major aspects such as imaging mode, AFM-based force spectroscopy and AFM-based fishing of low-abundance proteins. Each of them has a variety of possibilities to investigate physicochemical properties of proteins.

Dynamic mode of AFM imaging (tapping or oscillating mode) was developed to reduce friction and force between the tip and the sample. In this mode, cantilever is forced to oscillate close to its resonant frequency while contouring the sample [1,22]. The most popular dynamic modes use the oscillation amplitude of cantilever and its resonance frequency as feedback parameters because they change when the tip is near the sample surface $[1,4,24,25]$. There are also other variants of dynamic mode which use different signals as feedback or even induce cantilever oscillation at different frequencies [26]. In reality, interaction between the tip and the sample has quite a complex mechanism 
taking into account stiffness, roughness and surface charge of the sample. All those parameters could affect cantilever oscillation and change or invert topography contrast [26].

In an ideal visualization of soft biological objects, the AFM tip touches the sample surface at the very bottom of its downward movement. It helps to image objects which have a low adsorption on the support surface such as DNA, filaments and separate macromolecules of proteins [27-29]. Using AFM to study protein systems provided new insights into analysis of proteins [30,31], for example, measurements of structural and mechanical properties of single protein molecules in physiological buffers [32]; revealing the dynamic processes of single molecules including intermolecular [33-38] and intramolecular forces [39,40]; measurements of enzyme activity by detecting the motion of protein molecules [41]. AFM images of inorganic crystals have atomic resolution while resolution for biological objects is limited by submolecular level. The main areas of morphological AFM research of proteins have been formation of protein-nucleic acid or protein-protein complexes, oligomerization, and organization of protein molecules in biological membranes and Langmuir films [42,43].

Recent studies of water-soluble and membrane proteins revealed their submolecular details. Improvements in sample preparation $[44,45]$ and visualization techniques $[17,46]$ provided possibilities of imaging at subnanometer resolution. In the case of water-soluble proteins, image resolution is lower than one for membrane proteins which can form two-dimensional (2D) crystal layers [47].

AFM is widely used to measure heights and molecular volumes of protein molecules immobilized onto a support surface revealing their linear correlation with molecular weight [29,48-51].

Measuring the heights and molecular volumes of protein molecules allows to monitor a formation of protein complexes. Figure 2 presents a scheme of this monitoring process.

I AFM-visualisation of protein molecules
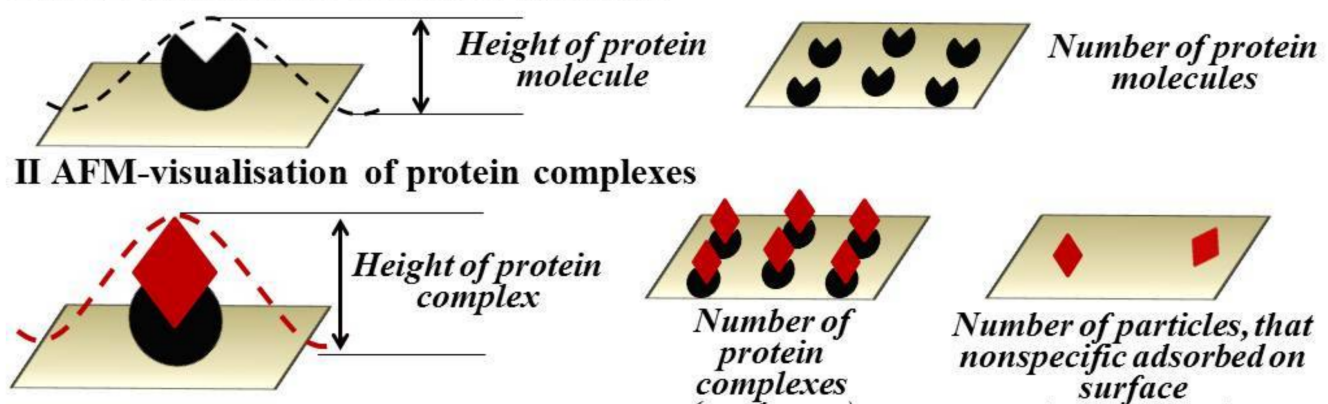

III AFM-data processing

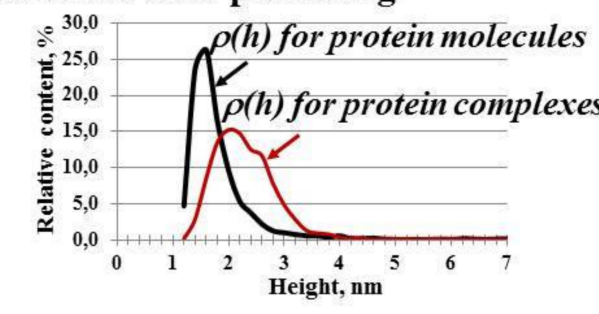

$\mathrm{S} / \mathrm{N}=\frac{\text { Protein complexes (work area) }}{\text { Particles (control area) }}$
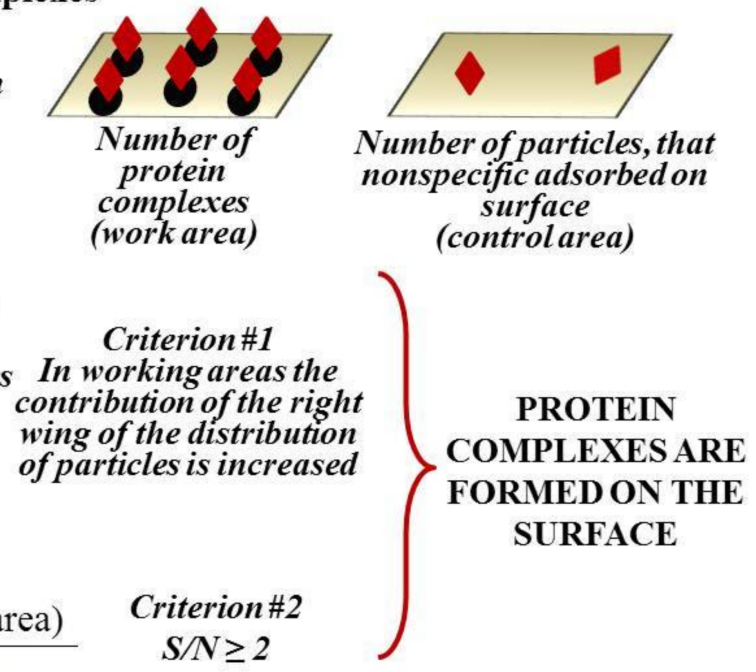

Figure 2. Sequence of stages of AFM measurements and data processing for obtaining information on stoichiometric parameters of protein macromolecules and protein complexes. At step (I), during the visualization by AFM, the height of biomolecules-components of protein complexes adsorbed (immobilized) on the support surface-is determined. At step (II), visualization of the surface after the incubation of the support in a solution of partner protein is carried out, and the height of the complexes is determined. At step (III) of processing of AFM data, relative distributions of the visualized objects with height $\rho(h)$ are plotted, and the number of these objects per unit area is calculated. If the data obtained meet the criteria \#1 and \#2, the formation of protein complexes on the support surface is confirmed. 
For instance, individual hepatitis $\mathrm{C}$ virus core-antigen (HCVcoreAg), antibodies against the hepatitis $\mathrm{C}$ virus core antigen (anti-HCVcoreAg) and their complex had significantly different heights of (1.5-2.0) nm, (1.5-2.0) $\mathrm{nm}$ and (5.0-7.0) nm, respectively [52].

An important application of AFM is studying the oligomeric state of proteins which may be useful for understanding the mechanisms of their functions. For example, cytochrome P450-containig monooxygenase systems oxidize a broad variety of endogenous and exogenous substrates thus they remain a high research interest [53]. The enzymatic P450 systems may be conventionally divided into two major groups: (I) single-protein self-sufficient systems (P450 102A1) [54], which do not require protein partners for the catalytic reaction to occur [55] and (II) more complicated, multiprotein systems (P450 101 [P450cam] responsible for camphor degradation, P450 11A1 [P450scc] responsible for cholesterol conversion to pregnenolone and P450 2B4 [P450LM2]), when catalytic reactions involve interaction with a protein partner [53,56-58]. The information on the enzyme's structure is very important for elucidation of the reaction mechanisms of (I) and (II) groups. AFM was capable of visualizing and obtaining the height of protein molecules and protein-protein complexes forming in those systems [59-68] in a tapping mode. Analysis of the density distribution with height $\rho(h)$ and its approximation allowed for the determination of parameters of single proteins as well as protein complexes.

AFM allowed to register formation of binary and ternary protein complexes in all the three P450101, P450 11A1 and P4502B4-containing monooxygenase systems [59]. For P450 101-containing system, AFM allowed to visualize the individual proteins PdR, Pd and P450 101 on mica and measure their heights $[67,69]$. The heights of proteins were estimated as $(2.6 \pm 0.3) \mathrm{nm}$ for (P450 101), $(2.0 \pm 0.3) \mathrm{nm}(\mathrm{Pd})$ and $(2.8 \pm 0.3) \mathrm{nm}(\mathrm{PdR})$ [67]. The fact that the actual sizes of proteins are somewhat less than those obtained by $\mathrm{X}$-ray crystallography or nuclear magnetic resonance spectroscopy was explained by the molecule contraction under the force applied by AFM tip. The binary PdR/Pd, $\mathrm{Pd} / \mathrm{P} 450101$ and PdR/P450 101 complexes were identified having their characteristic heights of $(4.9 \pm 0.3) \mathrm{nm},(4.3 \pm 0.3) \mathrm{nm}$ and $(5.1 \pm 0.3) \mathrm{nm}$ which were greater than those of single proteins. Along with the binary complexes, the ternary $\mathrm{PdR} / \mathrm{Pd} / \mathrm{P} 450101$ complexes were also registered. Accordingly, the characteristic heights of ternary $\mathrm{PdR} / \mathrm{Pd} / \mathrm{P} 450101$ complexes were in the range of (6.5-9.5) $\mathrm{nm}$ that was greater than those of binary complexes. The approach for obtaining the AFM images of isolated membrane proteins $\mathrm{Fp}, 2 \mathrm{~B} 4$ and b5 and their complexes involved monomerization procedure in solution with the use of Emulgen 913 at the first step followed by AFM registration and counting of proteins at the second step [65]. As was demonstrated during the course of this procedure, the membrane proteins became monomers while enzyme molecules retained their activity. Thus, the separately located Fp, 2B4 and b5 were visualized with the heights of $(2.2 \pm 0.2) \mathrm{nm},(2.3 \pm 0.2) \mathrm{nm}$ and $(1.8 \pm 0.1) \mathrm{nm}$, respectively. The binary $\mathrm{Fp} / 2 \mathrm{~B} 4$ and $2 \mathrm{~B} 4 / \mathrm{b} 5$ complexes were higher than isolated proteins: their characteristic heights were in the range over $2.7 \mathrm{~nm}$, with respective local maximums of $(3.4 \pm 0.2) \mathrm{nm}$ and $(2.8 \pm 0.2) \mathrm{nm}$ [65]. No formation of $\mathrm{Fp} / \mathrm{b} 5$ complexes was registered. The ternary $\mathrm{Fp} / 2 \mathrm{~B} 4 / \mathrm{b} 5$ complex heights were found to be in the range of (4.3-6.2) $\mathrm{nm}$.

AFM were used to monitor cytochrome CYP11A1 monomerization in solution without phospholipids [69]. It was shown that the incubation of CYP11A1 with 12\% Emulgen 913 led to dissociation of hemoprotein aggregates to monomers with the monomerization degree of $(82 \pm 4) \%$. Despite the monomerization procedure, CYP11A1 remained its functional activity. AFM was employed to detect and visualize the isolated proteins as well as complexes formed between the components of the cytochrome CYP11A1-dependent steroid hydroxylase system. Both Ad and AdR were present in solution as monomers. The typical heights of the monomeric AdR, Ad and CYP11A1 were $(1.6 \pm 0.2) \mathrm{nm},(1.0 \pm 0.2) \mathrm{nm}$ and $(1.8 \pm 0.2) \mathrm{nm}$, respectively. The binary Ad/AdR and AdR/CYP11A1mon complexes with the heights of $(2.2 \pm 0.2) \mathrm{nm}$ and $(2.8 \pm 0.2) \mathrm{nm}$, respectively, were also registered by AFM. In addition, the ternary AdR/Ad/CYP11A1 complexes with a typical height of $(4.0 \pm 1.0)$ nm were imaged.

Oligomerization degree was estimated for CYP102A1 protein using AFM visualization [60]. Immobilized protein molecules were visualized as monomers and oligomers. Objects with the height 
of $(2.2 \pm 0.1) \mathrm{nm}$ were referred to as monomers, objects with the height of $(3.4 \pm 0.7) \mathrm{nm}$ were referred to as oligomers. Share of objects was $(48 \pm 10) \%$ and $(52 \pm 10) \%$, respectively. It is known that the oligomeric form of CYP102A1 has a higher catalytic activity than its monomeric form [54], and AFM allowed to estimate directly the ratio between those forms.

In neurodegenerative disease studies a novel, on-surface aggregation pathway of amyloidogenic polypeptide was discovered. AFM was used to demonstrate directly that on-surface aggregation took place at a concentration at which aggregation in solution was not observed. The experiments were performed with the full-size $\beta$-amyloid peptide (A $\beta 42)$, a decapeptide $A \beta(14-23)$ and $\alpha$-synuclein; all three systems demonstrated a dramatic preference for the on-surface aggregation pathway compared to the aggregation in the bulk solution. Time-lapse AFM imaging in solution have shown that over time, oligomers grew in size and number and released in solution, suggesting that assembled aggregates can serve as nuclei for aggregation in bulk solution [70].

AFM ability to determine protein oligomeric state may be extended to test its activity. For instance, it was demonstrated that monoclonal antibodies were self-assembled into hexamers, which formed $2 \mathrm{D}$ crystals in aqueous solution. Direct observation of antibody-antigen interactions using frequency modulation atomic force microscopy (FM-AFM) revealed that immunoglobulin $\mathrm{G}(\mathrm{IgG})$ molecules in the crystal retained their immunoactivity [29].

An approach to measure the activity of single oligomers of the hemecontaining enzyme cytochrome P450 CYP102A1 (CYP102A1) by atomic force microscopy (AFM) has been demonstrated [63]. It was found that the amplitude of fluctuations of the height of single CYP102A1 molecules performing the catalytic cycle is twice as great as the amplitude of fluctuations of the height of the same enzymes in the inactive state. It was shown that the amplitude of height fluctuations of a CYP102A1 protein globule depends on temperature, the maximum of this dependence being observed at $22{ }^{\circ} \mathrm{C}$. The activity of a single CYP102A1 molecule in the unit amplitude of height fluctuations of a protein globule per unit time was $5 \pm 2 \AA$ s.

Limitation of standard AFM modes to study biomolecular processes is scanning speed. So, a high-speed AFM was developed to gain insights into mechanisms of molecular actions [71,72]. High-speed AFM was used to investigate the aggregation of $\alpha$-synuclein protein. $\alpha$-Synuclein is the major component of the intraneuronal inclusions called Lewy bodies which are the pathological hallmark of Parkinson's disease. This protein may self-assemble into many different species such as soluble oligomers and fibrils. A detailed understanding of these structures and their relationship with the different aggregation steps is lacking, while it can provide insight into the pathogenic mechanism of Parkinson's disease [73]. So, high-speed AFM has great potential but it is worth noting that experimental settings should be chosen carefully to not affect the results. It was shown that CYP102A1 deformation in a tapping mode with high-speed probes was greater compared to that in a tapping mode with standard probes. Increasing deformation led to the disappearance of CYP102A1 fluctuations during AFM monitoring of enzyme catalytic cycle [61].

Protein adsorption at solid-liquid interface has been a key topic in biomedical studies of biosensors and biochips [74], biomaterials [75,76], etc. Interaction force between protein and impervious surface depends on 3D protein structure and surface chemistry. Besides multiple studies on protein adsorption, it is still underexplored. A lot of methods based on different principles including infrared spectroscopy, Raman and circular dichroism spectroscopy, surface plasmon resonance spectroscopy, scanning electron microscopy and others has been engaged to study the interfacial properties of adsorbed proteins. However, all those methods provide averaged characteristics of biomolecules, while AFM allows to image adsorbed individual protein molecules under close to physiological conditions.

There is a high demand to overcome challenges of molecular and cell biology especially of drug design, which requires to study oligomerization, supramolecular structure and structural functions of membrane proteins in their native environment. Although only $30 \%$ of proteins encoded by the human genome are membrane proteins, they make $50 \%$ of all drug targets because of their stimulating and controlling functional activities of every life process [77]. Well-characterized membrane proteins 
have become convenient objects for AFM imaging at the beginning. One of the first studies was AFM visualization of native purple membranes of Halobacterium halobium [78] and visualization of 2D lattice of bacteriorhodopsin in them [79]. AFM allowed the identification of individual bacteriorhodopsin molecules on the purple membrane surface and revealed subnanometer features such as contribution of polypeptide chains to structural stability as barriers of protein unfolding [80,81]. Purple membranes adsorbed on mica were visualized in buffer solution by AFM, and it was found that its thickness depends on $\mathrm{pH}$ value of solution. Topography images of the cytoplasmic and extracellular surface also showed the same hexagonal lattice of bacteriorhodopsin [81]. Besides, a careful choice of experimental conditions increased a resolution of diffraction patterns up to $0.7 \mathrm{~nm}$ which gave an opportunity to resolve the structure of photoreactive unit with distance between its domains of $1.45 \mathrm{~nm}$ [42]. AFM observation of working ATP synthase allowed to image its 14 subunits rather than 10-12 ones predicted before [82]; that was the evidence of a submolecular level of AFM protein study.

\section{Force Spectroscopy Mode}

AFM is used not only for imaging. Force spectroscopy (FS) mode for investigation of elastic properties of protein molecules, which can be estimated from force distance (FD) curves obtained during the compressing stretching protein molecules under the probe force with the common setpoint limit of $\sim 1 \mathrm{nN}[1,83]$. AFM-based force spectroscopy (AFM-based FS) became one of the fundamental methods in the surface chemistry, biochemistry and materials science (Figure 1, right column).

AFM-based FS allows to determine and quantify the biophysical properties of proteins. Such properties can be obtained from the single FD curves recorded in the approach-retraction cycle of the probe movement towards and away from the sample, respectively $[1,84]$. The approach part of the curve is used to measure height, surface forces and mechanical deformation of the sample, and to estimate its elastic modulus and energy dissipation. The retraction part of the curve is used to estimate adhesion forces. To measure all these sample properties, it is required to have high-accuracy control of tip-sample interaction, and tip geometry and its surface properties should be known.

Force volume (FV) imaging combines topographic imaging and FD curves recording at any point for further processing $[1,84,85]$. FV mode allows to quantify elastic modulus along to other parameters, but it has insufficient resolution and low rate. Besides, results can be interpreted only after scan data processing and calculation of Young's modulus of the sample.

Among various models, Herz model has been widely applied to describe tip-surface contact omitting adhesion forces and to extract sample Young's modulus but it has lots of limitations for proteins [86]. Herz model was developed for a semi-infinite elastic sphere of homogenous and isotropic materials, and proteins are nonhomogeneous and nonisotropic. Despite that it has been used to obtain numerical measure of protein elasticity $[61,87]$.

One of the AFM-based FS modifications is a pulsed force mode when only the part of FD curve of tip pulling off the surface is recorded [88]. Lift mode is a two-passed method to measure the interaction forces while keeping constant the distance above the surface [85]. It is carried out after obtaining a standard topography image. It is also worth noting such abilities of various AFM-based FS modes as mapping the distribution of interaction forces automatically [22] and determining the local stiffness of materials (force modulation mode) [89].

In addition to real-time visualization of biological structures, AFM is used for direct measurement of adhesive forces between ligand and receptor. AFM-based FS allow to characterize individual interactions and complex formation instead of conventional studies of molecule population. AFM study of processes combining several different reactions (heterogeneity of interacting molecules, polyvalent binding or different combinations of complexes) may be conducted. The possibility of controlling the pull-off rate of cantilever, and thus the rate of breaking the complex of interacting partners, is an essential feature of AFM that allows for the estimation of the rupture forces along to kinetic and thermodynamic parameters of breaking the complex [2]. Different theoretical models are used to interpret AFM-based FS data and to convert values of rupture force and rate to thermodynamic and 
kinetic parameters of the reaction such as kinetic dissociation constant, Gibbs free energy, enthalpy, and entropy. The advantage of AFM is to measure the kinetic dissociation constant, which is not affected by reassociation events of ligand-receptor complexes occurring at the same time. Using AFM to study polyvalent interactions seems quite promising although it is a challenging task due to the complex stoichiometry of reaction. It is noteworthy that sample immobilization is necessary for AFM imaging, including covalent bonding, which is obviously one of the limitations of AFM.

The ability of AFM-based FS to measure interaction forces between ligand and receptor was demonstrated in the study of streptavidin-biotin pair under physiological conditions [90,91]. For the first time, interaction forces were measured between two surfaces functionalized with biotin, surfaces functionalized with streptavidin and biotin, and surfaces functionalized with biotin and biotin-streptavidin complex. In order to do that, attached to the AFM tip glass microsphere and mica surface were functionalized by biotin and streptavidin with covalent binding to bovine serum albumin (BSA) as a linkage. BSA have been non-specifically and irreversibly adsorbed onto glass and mica surfaces beforehand. There were not any residual forces between two biotinylated surfaces which made them suitable for measurement of biotin-streptavidin interaction forces in the piconewton range [42]. So far, adhesion forces between variety of ligand-receptor pairs such as biotin-avidin pair [92], antibody-antigen pair [93,94], between cell recognition proteins $[95,96]$ and others were measured by AFM. Moreover, it was shown that the value of adhesion force was not constant but it was dependent on experiment dynamics [92,97-99].

Almost all protein chains fold into a unique 3D structure which is well-organized and biologically active despite having a linear sequence of amino acids in a protein synthesis. Simple calculations provide the evidence that searching for unique native conformation, even for a small protein containing 100 amino acid residues, will occupy a million years using random conformational search. Therefore, mechanisms of folding and unfolding of protein are important topics of structural biology and physics. Stretching force curves can be obtained with the following procedure: AFM tip approaches a protein on the surface, touches it and retracts back stretching a protein $[1,19]$. This kind of AFM-based FS demonstrated that different proteins can be unfolded reversibly to reveal the essential properties of protein folding. A stretching technique was also implemented for unfolding of the single protein domains $[100,101]$. In this case differences in force values, which are required to unfold the molecule domains, can be quantified as well as compared to the folding topology; stability of secondary structural features can be analyzed; the rate constant of unfolding the single molecule can be estimated [19].

The obvious advantage of AFM to study protein (un)folding is that transitional steps of the process become visible. Combination of high-resolution AFM and single-molecule FS was applied to study the unfolding of single bacteriorhodopsin molecules from native purple membrane at various physiological temperatures and to obtain detailed understanding about stability of individual structural elements [102].

It was demonstrated that data obtained by FS experiments of protein (un)folding are comparable in quality and quantity to data obtained by standard techniques. Mechanical unfolding of single protein molecule by AFM is considered to have the same steps as the unfolding process observed by traditional folding techniques but the significant advantage of using AFM is the capability to determine the reaction coordinate and to reveal unique unfolding events which could not be found without chemical denaturants [103]. However, there is also a contrary opinion that mechanical unfolding of protein by AFM exposes an autonomous mechanism which depends on the direction of applied extension [104].

Modern FS-based AFMs can record over 100,000 FD curves, each of them describes local physical properties and interaction; such a map may be compared to topography image of a sample. A variety of FS-based modes have been developed to characterize sample properties during imaging [105]. Implemented to AFM device from NT-MDT (Zelenograd, Russia), point-to-point measurement tool allows simultaneous registration of sample topography image and its physical properties such as elastic, electrostatic, magnetic and other properties [85]. The main feature of the method is the absence of lateral forces because AFM probe moves off contact with the sample surface in lateral direction; this is crucial factor for the soft and weakly adsorbed objects. Registration of the force signal is 
conducted the same way as in contact mode when cantilever deflection is a feedback signal which is proportional to a normal force. Another tool implemented to AFM from Bruker (Santa Barbara, CA, USA) is Peak Force Tapping (PFT) mode [106]. This mode operates as tapping mode, but cantilever oscillates at low frequency of about $1 \mathrm{kHz}$ in a non-resonant mode with recording FD curve at every contact point with the sample surface. In PFT mode, topography image is obtained along with maps of adhesion force, energy dissipation, deformation and Young's modulus of sample. If cantilever was calibrated beforehand then all parameters would be mapped and quantified during imaging (Quantitative Nano-Mechanical PFT). PFT mode has an essential benefit of direct control of tip-sample interaction allowing to apply really low visualization forces to study biological objects.

There are two parameters of FS-based AFM which have a great influence on design and results of AFM experiments [105]. One of them is lateral resolution, which depends on the tip radius, the sample drift, distance dependence of the tip-sample interaction, imaging force and the properties of the biological sample. Another is the temporal resolution which depends on number of pixels recorded on the AFM image and the rate of obtaining FD curve. Development of new oscillation modes [107], improvement of piezo elements and feedback loops are used to increase AFM resolution. So modern FS-based AFM is able to obtain maps of $512 \times 512$ pixels (pxls) of different characteristics of biological objects under native conditions at resolution close to $1 \mathrm{~nm}$ in the range of time intervals of 15-30 min [105].

Besides FS and FV imaging, a technique called Molecular recognition was developed for mapping specific interaction between two molecules simultaneously with topography imaging [108-110]. Interaction occurs between a molecule attached to the AFM tip (chemical modification or immobilized ligand) and a molecule attached to the substrate surface (immobilized on the surface or localized in biological object, i.e., cell membrane). Topography and molecular recognition images (AFM-based TREC) can be compared to determine correlation of binding events and topographic profiles [111-113]. A variety of biomolecular systems have been studied using TREC imaging such as antigen-antibody [114], antibody-protein [115], cells [116,117], and other ligand-receptor pairs. For example, in [118], recognition of anti-gp120 aptamer was done using envelope glycoprotein gp120 of human immunodeficiency virus (HIV-1) as the probing molecule attached to the tip [110].

Recognition imaging has a lot of biomedical potential to study specific receptor binding sites on the cells [116] or even explore tissue samples [119].

In TREC mode, tip is functionalized by the probing molecule using flexible linkers [120] such as polyethylene glycol (PEG), DSP and so forth. Functionalized probe is oscillated with amplitude in the range of 5-10 nm during imaging and every recognition event causes reduction of the amplitude value. Imaging time in this case is comparable with standard imaging in a tapping mode. However, because FD curves are not registered, there is no quantitative characteristics of binding events, but only their localization can be obtained [110].

Binding specificity of functionalized tip with a sample is another problem that occurred during TREC imaging. Experimental design should be developed to identify specific interaction between ligand immobilized onto the tip and target receptor on the surface. Thus, control experiments should be conducted when undesired ligand-receptor interactions are blocked with chemicals or mutant cells without any specific recognition sites. Recognition imaging of living cells can be challenging because AFM probe can be easily contaminated during study. Weakly adsorbed objects may change the geometry of functionalized tip that would lead to inaccurate imaging. In this case design of experiment should include initial imaging and analyzing of sample by non-functionalized tip.

\section{AFM-Based Molecular Detector of Low-Abundance Proteins}

AFM provides the opportunity of protein visualization in a counting mode, which promises to use it as a molecular detector. Molecular detectors are a new generation of devices based on technologies and instruments which are used to detect single biomolecules in biological fluid. Proteomics and 
biomedical studies have a high demand for high-sensitivity analysis systems based on molecular detectors, and there are several reasons for that.

For diagnosis of cancer and viral diseases it was shown that a concentration detection limit (CDL) had to be lower than $10^{-15} \mathrm{M}$ [121]. However, most modern high-performance methods of proteomics such as mass-spectrometry with one- and two-dimensional electrophoresis or liquid chromatography (1- and 2-DE/LC MS) has CDL in the range from $10^{-12}$ to $10^{-14} \mathrm{M}[122,123]$. Therefore, it is necessary to increase a concentration sensitivity of analytical systems by several orders of magnitude to detect a high variety of low-abundance functional proteins having potential to be disease markers [123-125]. In the range of protein concentration from $10^{-12}$ to $10^{-14} \mathrm{M}$, only one thousand protein species can be detected in plasma which is a small part of total presumable amount of several million proteins [122,125,126].

The second reason for increasing the concentration sensitivity is a limited volume of sampling material (serum or plasma). In proteomics studies, serum is appealed to be of significant interest to search for disease biomarkers. It becomes an ideal biological sample since it is an information medium of the proteins released by diseased tissue. Variation in protein amount in response to pathogeneses makes serum an attractive clinical trial material. Calculations showed that the sample volume has to be of order $1 \mu \mathrm{L}$ for protein identification at concentration of $10^{-8} \mathrm{M}$ in serum by mass-spectrometer (MS). It has to be of order $10 \mathrm{~L}$ for protein identification at concentration of $10^{-15} \mathrm{M}$ that is obviously impossible in reality [123].

Analysis of serum proteome is also quite a challenging task because of the wide dynamic range of proteins. Detection of target analytes at low concentration involves some difficulties due to the presence of high-abundance proteins, high level of salt and other interfered compounds in serum [122,123].

AFM-based molecular detector combines a method itself and fishing technique (AFM-fishing) [127]. Fishing is a process of catching target proteins from solution using "bait" [128]. Molecular fishing is an adaptation of affinity enrichment of target molecules based on the specific interaction between immobilized ligand (bait molecule) and one or several assumed functional partners (captured molecule). Different molecules from small organic molecules to proteins and nucleic acids are able to be the bait molecules. Fishing technique have been implemented to a lot of biochemical methods.

AFM fishing (Figure 1, middle column) for detection of low-abundance proteins has two steps:

(1) fishing of biomolecules from a big volume of biological fluid onto a small surface (concentrating instead of conventional removal of high-abundance proteins by chromatography and electrophoresis used for protein matrix separation);

(2) high-sensitivity detection of caught molecules using AFM-based molecular detector (registering and counting the single molecules and molecular complexes).

During AFM-based fishing chip surface becomes bait area for concentrating the target proteins. Figure 3 presents the scheme of AFM-based fishing technique. Chip surface is functionalized by antibodies or aptamers in the case of biospecific analysis [122,123,127,129] (Figure 3, first step).

During chip incubation in analyzed fluid (Figure 3, second step) ligand-target complexes are formed on the chip surface functionalized by ligands. Chip surface is scanned by AFM to visualize (Figure 3, fourth step) and count formed complexes using the fact that the heights of complex components are smaller than the height of the whole complex. AFM-based fishing was applied to detect such serological marker as hepatitis $\mathrm{C}$ virus core-antigen (HCVcoreAg) in human serum using antibodies against the hepatitis $\mathrm{C}$ virus core antigen (anti-HCVcoreAg) as bait $[52,130]$. After incubation of AFM chip functionalized with anti-HCVcoreAg molecules in analyzed solution contained HCV coreAg, the size of objects on the surface was supposed to grow due to antigen-antibody complex formation. It was demonstrated that the anti-HCV coreAg height was in the range of (1-1.5) nm (ligand), the HCVcoreAg height was in the range of (1.5-2) nm, height of their complexes was in the range of (3-7) nm, thus the heights of ligand and target proteins were smaller than the height of antibody-antigen complex as was supposed. 


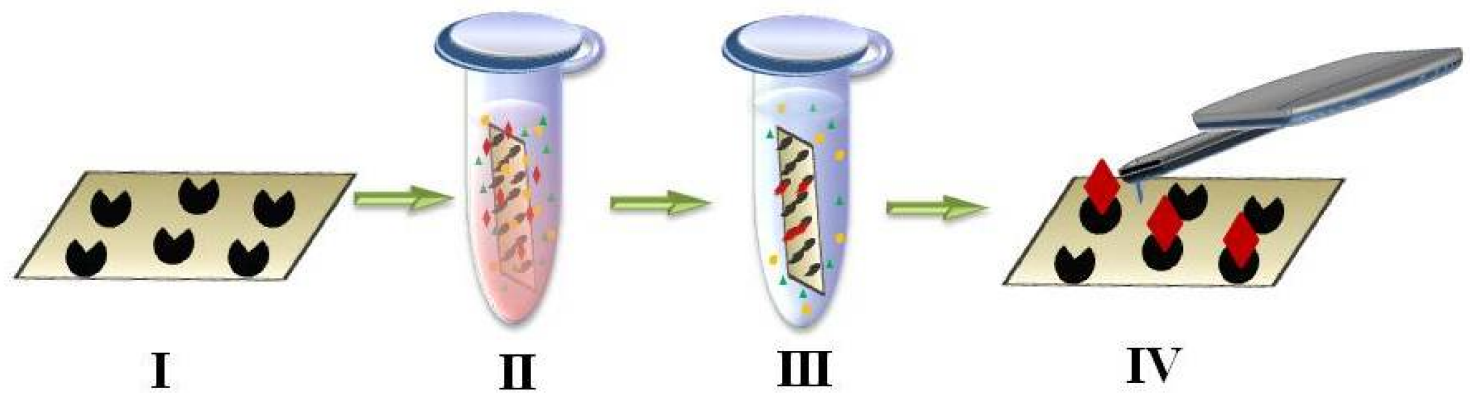

Figure 3. Experimental design of AFM-based fishing includes the following steps: (I) functionalization of the chip by immobilizing the bait molecules for further biospecific registration of protein complexes; (II) biospecific fishing of protein from solution during chip incubation in analyzed fluid; (III) chip rinsing to remove the components adsorbed nonspecifically onto the surface; (IV) AFM imaging in a counting mode to detect protein complexes.

AFM image processing and counting of macromolecules and their complexes on the chip surface are carried out using software which allows to recognize the images of objects on the AFM chip, distinguish them by geometrical dimensions and obtain their height distribution.

Biospecific AFM-based fishing can implement reversible or irreversible procedures. In reversible fishing, number of complexes formed on the surface is determined by dissociation constant $K d$. In irreversible fishing, complexes formed on the surface are additionally covalently cross-linked so that it converts reversible complexing reaction to irreversible one and increase concentration sensitivity of detection of protein complexes due to lifting $K d$ limit.

Using the same ligand-target pair of anti-HCVcore/HCVcoreAg it was shown that irreversible biospecific fishing combined with AFM-based detection of molecules enabled to register HCVcoreAg having four orders less concentration of up to $10^{-16} \mathrm{M}$ in solution compared to the reversible fishing approach [6]. If this registration scheme will be optimized, estimation predicted a capability of further increasing sensitivity by two orders of magnitude. Conversion of reversible bonding into irreversible one increases sensitivity of AFM-based fishing as well as other analytical systems. Detection method of low- and ultralow-abundance proteins in biomaterial can combine concentrating the protein from the sample onto cyanogen bromide-activated Sepharose $4 \mathrm{~B}$ (via nonspecific binding of free amino groups) and multiple reaction monitoring MS (MRM-MS) [131]. The detection limit and the dependence of the MRM peak areas on the concentration of protein in the sample were determined using the proteins CYP102 and BSA as model system: both proteins in solution and after their addition to human plasma. Nonspecific protein enrichment of proteins from diluted sample volumes of $10-50 \mathrm{~mL}$ was found to increase the range of linear dependence of the chromatographic peak area on concentration by more than three orders of magnitude allowing to reach LOD limit (LLOD) as low as $10^{-18} \mathrm{M}$.

Another challenge for AFM-based molecular detection technique is fishing and registration of target proteins from not only model buffer solution but from biological fluid such as blood serum. This technique was applied for detection of hepatitis $C$ and hepatitis B virus particles in serum [52,130]. After incubation of chip functionalized by anti-HCVcoreAg in the blood serum contained hepatitis $\mathrm{C}$ virus, new objects with height in the range of 10-35 nm were imaged using AFM while there were no such objects in the control negative serum. Typical objects in the control experiment had height less than $5 \mathrm{~nm}$. A similar registration scheme was applied for detection of hepatitis B viruses. In this case, objects with height in the range of 10-40 nm were observed after incubation of AFM chip with immobilized antibodies against the hepatitis B virus antigen (HBsAg) in serum. MS confirmed selectivity of proposed analytical system for detection of marker proteins of hepatitis $C$ virus using AFM chips functionalized by antibodies [132,133].

AFM-based fishing can be applied to identification of disease markers of different categories such as infectious and somatic diseases including cancer. Specificity of analysis will be determined by specificity of the ligands (antibodies or aptamers) immobilized on the chip surface. AFM chips 
functionalized by aptamers (aptamer-based approach) have been applied to carry out AFM-based fishing of envelope glycoprotein gp120 of human immunodeficiency virus (HIV-1) used as biomarker in diagnosis [118]. In aptamer-based approach, the increase of AFM image contrast was observed compared to antibody-based approach when antibodies have been used as bait molecules $[118,129,134]$. MS analysis allowed to identify the target protein from the chip surface after biospecific fishing that proved aptamer-protein complex formation.

AFM chips having not only one bait spot but a two-dimensional matrix of them are the most promising for diagnostic purposes. Such a matrix of bait spots is a microarray of macromolecules used as baits of proteins associated with different diseases. AFM-based detector combined with the chip assay was implemented to AFM-immunosensor (AFMIS) technology by BioForce (USA) for fast, sensitive and noninvasive detection of viruses $[135,136]$. The developed platform couples AFM registration with a silicon chip with ultramicrospots of antibodies (20 spots per chip). For multiplex analysis, AFM chip can be also made of mica [137].

To provide a visual orientation and precise cantilever positioning above each spot for further AFM imaging, a method of surface marking was developed on the base of formation the optically visible metallic marks on the AFM chip using magnetron sputtering device [137].

\section{Conclusions}

AFM provides the unique opportunity to study structural and physical characteristics of protein molecules. A wide range of measuring techniques can be combined or used separately. The advantages of AFM include the following: it is non-destructive and high-resolution imaging tool; it does not require complex sample preparation; the ability to operate in air or liquid while obtaining information on a wide range of physical properties of the sample.

Development of the instruments of the latest generation-for instance, BioScope Resolve ${ }^{\mathrm{TM}}$ BioAFM [138], which allow simultaneous registration of several signals with independent channels determines the application of AFM as the basis for a novel nanotechnology platform. The use of this platform for simultaneous visualization, determination of stoichiometric and physicochemical properties of biomacromolecules, including the activity of single enzyme molecules, is promising. Introduction of serial high-speed instruments will allow one to employ AFM for solving the tasks of medical diagnostics, and to introduce the method of AFM-based fishing into the wide practice for the detection of medically relevant proteins. The combination of a high-speed scanning and a multiprobe instrument [139] will be promising for the use in proteomic screening.

AFM has great potential when combined with other study approaches. Analysis methods of AFM and mass spectrometry have been combined for visualization and further identification of the protein and protein-protein complexes. AFM-based fishing allows the detection of the low-abundance proteins and characterization of their properties. Such alliances are especially useful to solve problems of proteomics and medical diagnostics.

One of the major disadvantages of AFM have been an impossibility of performing the chemical analysis of a sample. Combining AFM with infrared and other near-field spectroscopy methods can effectively become a technique to overcome that and to obtain data of mechanical properties in relation to chemical analysis at the nanolevel $[140,141]$. Novel methods are able to retain the high-resolution AFM imaging as well as to analyze a variety of physical, morphological and chemical properties of materials from living tissues to nanotechnology products.

Acknowledgments: This study was supported by Russian Science Foundation (Grant No. 14-25-00132).

Conflicts of Interest: The authors declare no conflicts of interest. 


\section{References}

1. Hinterdorfer, P.; Oijen, A. Handbook of Single-Molecule Biophysics. CERN Doc. Serv. 2009. [CrossRef]

2. Safenkova, I.V.; Zherdev, A.V.; Dzantiev, B.B. Application of atomic force microscopy for characteristics of single intermolecular interactions. Biochem. Mosc. 2012, 77, 1536-1552. [CrossRef] [PubMed]

3. Binnig, G.; Quate, C.F.; Gerber, C. Atomic Force Microscope. Phys. Rev. Lett. 1986, 56, 930-933. [CrossRef] [PubMed]

4. Dufrêne, Y.F.; Ando, T.; Garcia, R.; Alsteens, D.; Martinez-Martin, D.; Engel, A.; Gerber, C.; Müller, D.J. Imaging modes of atomic force microscopy for application in molecular and cell biology. Nat. Nanotechnol. 2017, 12, 295. [CrossRef] [PubMed]

5. Miller, J.L. Force spectroscopy unveils hidden protein-folding states. Phys. Today 2017, 70, 16-18. [CrossRef]

6. Hoh, J.H.; Schoenenberger, C.A. Surface morphology and mechanical properties of MDCK monolayers by atomic force microscopy. J. Cell Sci. 1994, 107, 1105-1114. [PubMed]

7. Henderson, E.; Haydon, P.G.; Sakaguchi, D.S. Actin filament dynamics in living glial cells imaged by atomic force microscopy. Science 1992, 257, 1944-1946. [CrossRef] [PubMed]

8. Hoh, J.H.; Lal, R.; John, S.A.; Revel, J.P.; Arnsdorf, M.F. Atomic force microscopy and dissection of gap junctions. Science 1991, 253, 1405-1408. [CrossRef] [PubMed]

9. Mou, J.; Yang, J.; Shao, Z. Atomic Force Microscopy of Cholera Toxin B-oligomers Bound to Bilayers of Biologically Relevant Lipids. J. Mol. Biol. 1995, 248, 507-512. [CrossRef] [PubMed]

10. Hansma, H.G.; Vesenka, J.; Siegerist, C.; Kelderman, G.; Morrett, H.; Sinsheimer, R.L.; Elings, V.; Bustamante, C.; Hansma, P.K. Reproducible imaging and dissection of plasmid DNA under liquid with the atomic force microscope. Science 1992, 256, 1180-1184. [CrossRef] [PubMed]

11. Limanskaya, O.Y.; Limanskii, A.P. Imaging compaction of single supercoiled DNA molecules by atomic force microscopy. Gen. Physiol. Biophys. 2008, 27, 322-337. [PubMed]

12. Kwak, K.J.; Kudo, H.; Fujihira, M. Imaging stretched single DNA molecules by pulsed-force-mode atomic force microscopy. Ultramicroscopy 2003, 97, 249-255. [CrossRef]

13. Egger, M.; Ohnesorge, F.; Weisenhorn, A.L.; Heyn, S.P.; Drake, B.; Prater, C.B.; Gould, S.A.C.; Hansma, P.K.; Gaub, H.E. Wet lipid-protein membranes imaged at submolecular resolution by atomic force microscopy. J. Struct. Biol. 1990, 103, 89-94. [CrossRef]

14. Hansma, H.G.; Gould, S.A.C.; Hansma, P.K.; Gaub, H.E.; Longo, M.L.; Zasadzinski, J.A.N. Imaging nanometer scale defects in Langmuir-Blodgett films with the atomic force microscope. Langmuir 1991, 7, 1051-1054. [CrossRef]

15. Chi, L.F.; Anders, M.; Fuchs, H.; Johnston, R.R.; Ringsdorf, H. Domain Structures in Langmuir-Blodgett Films Investigated by Atomic Force Microscopy. Science 1993, 259, 213-216. [CrossRef] [PubMed]

16. Yang, J.; Mou, J.; Shao, Z. Structure and stability of pertussis toxin studied by in situ atomic force microscopy. FEBS Lett. 1994, 338, 89-92. [CrossRef]

17. Müller, D.J.; Fotiadis, D.; Scheuring, S.; Müller, S.A.; Engel, A. Electrostatically Balanced Subnanometer Imaging of Biological Specimens by Atomic Force Microscope. Biophys. J. 1999, 76, 1101-1111. [CrossRef]

18. Schabert, F.A.; Henn, C.; Engel, A. Native Escherichia coli OmpF porin surfaces probed by atomic force microscopy. Science 1995, 268, 92-94. [CrossRef] [PubMed]

19. Silva, L.P. Imaging proteins with atomic force microscopy: An overview. Curr. Protein Pept. Sci. 2005, 6, 387-395. [CrossRef] [PubMed]

20. Kada, G.; Kienberger, F.; Hinterdorfer, P. Atomic force microscopy in bionanotechnology. Nano Today 2008, 3 , 12-19. [CrossRef]

21. Müller, D.J.; Engel, A.; Carrascosa, J.L.; Vélez, M. The bacteriophage $\varphi 29$ head-tail connector imaged at high resolution with the atomic force microscope in buffer solution. EMBO J. 1997, 16, 2547-2553. [CrossRef] [PubMed]

22. Bykov, I.V.; Bykov, V.A. Attraction and repulsion regime of semicontact mode atomic force microscopy. Automatized methods for optimization of operation in attraction regime. Izvestiya Vysshikh Uchebnykh Zavedenii. Materialy Elektronnoi Tekhniki 2008, 1, 75-77.

23. Engel, A.; Müller, D.J. Observing single biomolecules at work with the atomic force microscope. Nat. Struct. Mol. Biol. 2000, 7, 715. [CrossRef] [PubMed] 
24. Albrecht, T.R.; Grütter, P.; Horne, D.; Rugar, D. Frequency modulation detection using high-Q cantilevers for enhanced force microscope sensitivity. J. Appl. Phys. 1991, 69, 668-673. [CrossRef]

25. Putman, C.A.J.; van der Werf, K.O.; de Grooth, B.G.; Van Hulst, N.F.; Greve, J. Tapping mode atomic force microscopy in liquid. Appl. Phys. Lett. 1994, 64, 2454-2456. [CrossRef]

26. Garcia, R.; Herruzo, E.T. The emergence of multifrequency force microscopy. Nat. Nanotechnol. 2012, 7, 217. [CrossRef] [PubMed]

27. Hansma, P.K.; Cleveland, J.P.; Radmacher, M.; Walters, D.A.; Hillner, P.E.; Bezanilla, M.; Fritz, M.; Vie, D.; Hansma, H.G.; Prater, C.B.; et al. Tapping mode atomic force microscopy in liquids. Appl. Phys. Lett. 1994, 64, 1738-1740. [CrossRef]

28. Ido, S.; Kimura, K.; Oyabu, N.; Kobayashi, K.; Tsukada, M.; Matsushige, K.; Yamada, H. Beyond the Helix Pitch: Direct Visualization of Native DNA in Aqueous Solution. ACS Nano 2013, 7, 1817-1822. [CrossRef] [PubMed]

29. Ido, S.; Kimiya, H.; Kobayashi, K.; Kominami, H.; Matsushige, K.; Yamada, H. Immunoactive two-dimensional self-assembly of monoclonal antibodies in aqueous solution revealed by atomic force microscopy. Nat. Mater. 2014, 13, 264. [CrossRef] [PubMed]

30. Kienberger, F.; Stroh, C.; Kada, G.; Moser, R.; Baumgartner, W.; Pastushenko, V.; Rankl, C.; Schmidt, U.; Müller, H.; Orlova, E.; LeGrimellec, C. Dynamic force microscopy imaging of native membranes. Ultramicroscopy 2003, 97, 229-237. [CrossRef]

31. Scheuring, S.; Seguin, J.; Marco, S.; Levy, D.; Breyton, C.; Robert, B.; Rigaud, J.L. AFM characterization of tilt and intrinsic flexibility of rhodobacter sphaeroides light harvesting complex 2 (LH2). J. Mol. Biol. 2003, 325, 569-580. [CrossRef]

32. Radmacher, M.; Fritz, M.; Cleveland, J.P.; Walters, D.A.; Hansma, P.K. Imaging adhesion forces and elasticity of lysozyme adsorbed on mica with the atomic force microscope. Langmuir 1994, 10, 3809-3814. [CrossRef]

33. Alonso, J.L.; Goldmann, W.H. Feeling the forces: Atomic force microscopy in cell biology. Life Sci. 2003, 72, 2553-2560. [CrossRef]

34. Fotiadis, D.; Scheuring, S.; Müller, S.A.; Engel, A.; Müller, D.J. Imaging and manipulation of biological structures with the AFM. Micron 2002, 33, 385-397. [CrossRef]

35. Zlatanova, J.; Lindsay, S.M.; Leuba, S.H. Single molecule force spectroscopy in biology using the atomic force microscope. Prog. Biophys. Mol. Biol. 2000, 74, 37-61. [CrossRef]

36. Stolz, M.; Stoffler, D.; Aebi, U.; Goldsbury, C. Monitoring biomolecular interactions by time-lapse atomic force microscopy. J. Struct. Biol. 2000, 131, 171-180. [CrossRef] [PubMed]

37. Bustamante, C.; Smith, S.B.; Liphardt, J.; Smith, D. Single-molecule studies of DNA mechanics. Curr. Opin. Struct. Biol. 2000, 10, 279-285. [CrossRef]

38. Rief, M.; Oesterhelt, F.; Heymann, B.; Gaub, H.E. Single molecule force spectroscopy on polysaccharides by atomic force microscopy. Science 1997, 275, 1295-1297. [CrossRef] [PubMed]

39. Vengasandra, S.; Sethumadhavan, G.; Yan, F.; Wang, R. Studies on the protein-receptor interaction by atomic force microscopy. Langmuir 2003, 19, 10940-10946. [CrossRef]

40. Zhang, J.; Liu, X.Y. Effect of protein-protein interactions on protein aggregation kinetics. J. Chem. Phys. 2003, 119, 10972-10976. [CrossRef]

41. Thomson, N.H.; Fritz, M.; Radmacher, M.; Cleveland, J.P.; Schmidt, C.F.; Hansma, P.K. Protein tracking and detection of protein motion using atomic force microscopy. Biophys. J. 1996, 70, 2421-2431. [CrossRef]

42. Kiselyova, O.I.; Yaminsky, I.V. Atomic force microscopy of protein complexes. In Atomic Force Microscopy; Humana Press: New York, NY, USA, 2004; pp. 217-230.

43. Silva, L.P. Atomic force microscopy investigation of ribonuclease A. Protein Pept. Lett. 2001, 8, $343-347$. [CrossRef]

44. Wagner, P. Immobilization strategies for biological scanning probe microscopy 1. FEBS Lett. 1998, 430, 112-115. [CrossRef]

45. Müller, D.J.; Amrein, M.; Engel, A. Adsorption of biological molecules to a solid support for scanning probe microscopy. J. Struct. Biol. 1997, 119, 172-188. [CrossRef] [PubMed]

46. Hafner, J.H.; Cheung, C.-L.; Woolley, A.T.; Lieber, C.M. Structural and functional imaging with carbon nanotube AFM probes. Prog. Biophys. Mol. Biol. 2001, 77, 73-110. [CrossRef]

47. Alessandrini, A.; Facci, P. AFM: A versatile tool in biophysics. Meas. Sci. Technol. 2005, 16, R65. [CrossRef] 
48. Schneider, S.W.; Lärmer, J.; Henderson, R.M.; Oberleithner, H. Molecular weights of individual proteins correlate with molecular volumes measured by atomic force microscopy. Pflüg. Arch. 1998, 435, 362-367. [CrossRef] [PubMed]

49. Thomson, N.H. Imaging the substructure of antibodies with tapping-mode AFM in air: The importance of a water layer on mica. J. Microsc. 2005, 217, 193-199. [CrossRef] [PubMed]

50. Rodriguez-Ramos, J.; Perrino, A.P.; Garcia, R. Dependence of the volume of an antibody on the force applied in a force microscopy experiment in liquid. Ultramicroscopy 2016, 171, 153-157. [CrossRef] [PubMed]

51. Barinov, N.; Ivanov, N.; Kopylov, A.; Klinov, D.; Zavyalova, E. Direct visualization of the oligomeric state of hemagglutinins of influenza virus by high-resolution atomic force microscopy. Biochimie 2018, 146, 148-155. [CrossRef] [PubMed]

52. Ivanov, Y.D.; Frantsuzov, P.A.; Pleshakova, T.O.; Ziborov, V.S.; Svetlov, S.K.; Krokhin, N.V.; Konev, V.A.; Kovalev, O.B.; Uchařkin, V.F.; Iastrebova, O.N.; et al. Atomic force microscopy detection of serological markers of viral hepatites B and C. Biochem. Mosc. Suppl. Ser. B Biomed. Chem. 2010, 4, 117-122. [CrossRef]

53. Archakov, A.I.; Bachmanova, G.I. Cytochrome P-450 and active oxygen. Trends Biochem. Sci. 1990. [CrossRef]

54. Neeli, R.; Girvan, H.M.; Lawrence, A.; Warren, M.J.; Leys, D.; Scrutton, N.S.; Munro, A.W. The dimeric form of flavocytochrome P450 BM3 is catalytically functional as a fatty acid hydroxylase. FEBS Lett. 2005, 579, 5582-5588. [CrossRef] [PubMed]

55. Narhi, L.O.; Fulco, A.J. Characterization of a catalytically self-sufficient 119,000-dalton cytochrome P-450 monooxygenase induced by barbiturates in Bacillus megaterium. J. Biol. Chem. 1986, 261, 7160-7169. [PubMed]

56. Bernhardt, R. Cytochrome P450: Structure, function, and generation of reactive oxygen species. In Reviews of Physiology Biochemistry and Pharmacology; Springer: Berlin/Heidelberg, Germany, 1995; Volume 127, pp. 137-221.

57. De Montellano, P.R.O. Cytochrome P450: Structure, Mechanism, and Biochemistry; Springer Science \& Business Media: Berlin, Germany, 2005.

58. Lewis, D.F.V. Guide to Cytochromes: Structure and Function; CRC Press: Boca Raton, FL, USA, 1996.

59. Archakov, A.I.; Ivanov, Y.D. Application of AFM and optical biosensor for investigation of complexes formed in P450-containing monooxygenase systems. Biochim. Biophys. Acta Proteins Proteom. 2011, 1814, 102-110. [CrossRef] [PubMed]

60. Ivanov, Y.D.; Bukharina, N.S.; Frantsuzov, P.A.; Pleshakova, T.O.; Kanashenko, S.L.; Medvedeva, N.V.; Argentova, V.V.; Zgoda, V.G.; Munro, A.W.; Archakov, A.I. AFM study of cytochrome CYP102A1 oligomeric state. Soft Matter 2012, 8, 4602-4608. [CrossRef]

61. Bukharina, N.S.; Pleshakova, T.O.; Ziborov, V.S.; Fokin, D.A.; Ivanova, N.D.; Ivanov, Y.D. Atomic force microscopy analysis of deformation of single cytochrome CYP102A1 molecules. Sci. Adv. Mater. 2017, 9, 135-143. [CrossRef]

62. Ivanov, Y.D.; Bukharina, N.S.; Frantsuzov, P.A.; Pleshakova, T.O.; Krohin, N.V.; Kanashenko, S.L.; Archakov, A.I. Oligomeric state investigation of flavocytochrome CYP102A1 using AFM with standard and supersharp probes. Biochem. Mosc. Suppl. Ser. B Biomed. Chem. 2012, 6, 218-224. [CrossRef]

63. Ivanov, Y.D.; Bukharina, N.S.; Pleshakova, T.O.; Frantsuzov, P.A.; Krokhin, N.V.; Ziborov, V.S.; Archakov, A.I. Atomic force microscopy visualization and measurement of the activity and physicochemical properties of single monomeric and oligomeric enzymes. Biophysics 2011, 56, 892-896. [CrossRef]

64. Ivanov, Y.D.; Frantsuzov, P.A.; Bykov, V.A.; Besedin, S.P.; Hoa, G.H.B.; Archakov, A.I. Comparative investigation of PdR by usual and ultrafine atomic force microscopy. Anal. Methods 2010, 2, 688-693. [CrossRef]

65. Kuznetsov, V.Y.; Ivanov, Y.D.; Archakov, A.I. Atomic force microscopy revelation of molecular complexes in the multiprotein cytochrome P450 2B4-containing system. Proteomics 2004, 4, 2390-2396. [CrossRef] [PubMed]

66. Dmitriev, D.A.; Massino, Y.S.; Segal, O.L.; Smirnova, M.B.; Pavlova, E.V.; Gurevich, K.G.; Gnedenko, O.V.; Ivanov, Y.D.; Kolyaskina, G.I.; Archakov, A.I.; et al. Analysis of the binding of bispecific monoclonal antibodies with immobilized antigens (human IgG and horseradish peroxidase) using a resonant mirror biosensor. J. Immunol. Methods 2002, 261, 103-118. [CrossRef]

67. Kuznetsov, V.Y.; Ivanov, Y.D.; Bykov, V.A.; Saunin, S.A.; Fedorov, I.A.; Lemeshko, S.V.; Hoa, H.B.; Archakov, A.I. Atomic force microscopy detection of molecular complexes in multiprotein P450cam containing monooxygenase system. Proteomics 2002, 2, 1699-1705. [CrossRef] 
68. Kiselyova, O.I.; Yaminsky, I.V.; Ivanov, Y.D.; Kanaeva, I.P.; Kuznetsov, V.Y.; Archakov, A.I. AFM study of membrane proteins, cytochrome P450 2B4, and NADPH- cytochrome P450 reductase and their complex formation. Arch. Biochem. Biophys. 1999, 371, 1-7. [CrossRef] [PubMed]

69. Ivanov, Y.D.; Frantsuzov, P.A.; Zöllner, A.; Medvedeva, N.V.; Archakov, A.I.; Reinle, W.; Bernhardt, R. Atomic Force Microscopy Study of Protein-Protein Interactions in the Cytochrome CYP11A1 (P450scc)-Containing Steroid Hydroxylase System. Nanoscale Res. Lett. 2011, 6, 1-13. [CrossRef] [PubMed]

70. Banerjee, S.; Hashemi, M.; Lv, Z.; Maity, S.; Rochet, J.C.; Lyubchenko, Y.L. A novel pathway for amyloids self-assembly in aggregates at nanomolar concentration mediated by the interaction with surfaces. Sci. Rep. 2017, 7, 45592. [CrossRef] [PubMed]

71. Uchihashi, T.; Scheuring, S. Applications of high-speed atomic force microscopy to real-time visualization of dynamic biomolecular processes. Biochim. Biophys. Acta BBA Gen. Subj. 2018, 1862, 229-240. [CrossRef] [PubMed]

72. Ando, T. High-speed AFM imaging. Curr. Opin. Struct. Biol. 2014, 28, 63-68. [CrossRef] [PubMed]

73. Zhang, Y.; Hashemi, M.; Lv, Z.; Williams, B.; Popov, K.I.; Dokholyan, N.V.; Lyubchenko, Y.L. High-speed atomic force microscopy reveals structural dynamics of $\alpha$-synuclein monomers and dimers. J. Chem. Phys. 2018, 148, 123322. [CrossRef] [PubMed]

74. Lee, W.; Oh, B.K.; Bae, Y.M.; Paek, S.H.; Lee, W.H.; Choi, J.W. Fabrication of self-assembled protein A monolayer and its application as an immunosensor. Biosens. Bioelectron. 2003, 19, 185-192. [CrossRef]

75. Lacava, B.M.; Azevedo, R.B.; Silva, L.P.; Lacava, Z.G.M.; Neto, K.S.; Buske, N.; Bakuzis, A.F.; Morais, P.C. Particle sizing of magnetite-based magnetic fluid using atomic force microscopy: A comparative study with electron microscopy and birefringence. Appl. Phys. Lett. 2000, 77, 1876-1878. [CrossRef]

76. Silva, L.P.; Lacava, Z.G.M.; Buske, N.; Morais, P.C.; Azevedo, R.B. Atomic force microscopy and transmission electron microscopy of biocompatible magnetic fluids: A comparative analysis. J. Nanopart. Res. 2004, 6, 209-213. [CrossRef]

77. Muller, D.J. Out and In: Simplifying Membrane Protein Studies by AFM. Biophys. J. 2006, 91, 3133-3134. [CrossRef] [PubMed]

78. Worcester, D.L.; Miller, R.G.; Bryant, P.J. Atomic force microscopy of purple membranes. J. Microsc. 1988, 152, 817-821. [CrossRef] [PubMed]

79. Worcester, D.L.; Kim, H.S.; Miller, R.G.; Bryant, P.J. Imaging bacteriorhodopsin lattices in purple membranes with atomic force microscopy. J. Vac. Sci. Technol. Vac. Surf. Films 1990, 8, 403-405. [CrossRef]

80. Müller, D.J.; Kessler, M.; Oesterhelt, F.; Möller, C.; Oesterhelt, D.; Gaub, H. Stability of Bacteriorhodopsin $\alpha$-Helices and Loops Analyzed by Single-Molecule Force Spectroscopy. Biophys. J. 2002, 83, 3578-3588. [CrossRef]

81. Müller, D.J.; Schabert, F.A.; Büldt, G.; Engel, A. Imaging purple membranes in aqueous solutions at sub-nanometer resolution by atomic force microscopy. Biophys. J. 1995, 68, 1681-1686. [CrossRef]

82. Seelert, H.; Poetsch, A.; Dencher, N.A.; Engel, A.; Stahlberg, H.; Müller, D.J. Structural biology: Proton-powered turbine of a plant motor. Nature 2000, 405, 418. [CrossRef] [PubMed]

83. Choi, S.; Jung, G.B.; Kim, K.S.; Lee, G.-J.; Park, H.-K. Medical Applications of Atomic Force Microscopy and Raman Spectroscopy. J. Nanosci. Nanotechnol. 2014, 14, 71-97. [CrossRef] [PubMed]

84. Neuman, K.C.; Nagy, A. Single-molecule force spectroscopy: Optical tweezers, magnetic tweezers and atomic force microscopy. Nat. Methods 2008, 5, 491. [CrossRef] [PubMed]

85. Bykov, I.V. Point measurements of topography, interaction forces and local properties: New approach to the complex analysis in atomic force microscopy. Nauchnoe Priborostr. 2009, 19, 38-43.

86. Berquand, A.; Hella-Monika, K.; Andreas, H.; Jan, M.; Petra, K. Expression of tumor suppressors PTEN and TP53 in isogenic glioblastoma U-251MG Cells affects cellular mechanical properties-An AFM-based quantitative investigation. JJAP Conf. Proc. 2013. [CrossRef]

87. Rehana, A.; Alam Mohammad, T.; Atsushi, I. Pretransition and progressive softening of bovine carbonic anhydrase II as probed by single molecule atomic force microscopy. Protein Sci. 2009, 14, 1447-1457.

88. Rosa-Zeiser, A.; Weilandt, E.; Hild, S.; Marti, O. The simultaneous measurement of elastic, electrostatic and adhesive properties by scanning force microscopy: Pulsed-force mode operation. Meas. Sci. Technol. 1997, 8 , 1333. [CrossRef] 
89. Maivald, P.; Butt, H.J.; Gould, S.A.C.; Prater, C.B.; Drake, B.; Gurley, J.A.; Elings, V.B.; Hansma, P.K. Using force modulation to image surface elasticities with the atomic force microscope. Nanotechnology 1991, 2, 103. [CrossRef]

90. Lee, G.U.; Kidwell, D.A.; Colton, R.J. Sensing discrete streptavidin-biotin interactions with atomic force microscopy. Langmuir 1994, 10, 354-357. [CrossRef]

91. Moy, V.T.; Florin, E.-L.; Gaub, H.E. Adhesive forces between ligand and receptor measured by AFM. Colloids Surf. Physicochem. Eng. Asp. 1994, 93, 343-348. [CrossRef]

92. Lo, Y.-S.; Simons, J.; Beebe, T.P. Temperature dependence of the biotin-avidin bond-rupture force studied by atomic force microscopy. J. Phys. Chem. B 2002, 106, 9847-9852. [CrossRef]

93. Harada, Y.; Kuroda, M.; Ishida, A. Specific and quantized antigen-antibody interaction measured by atomic force microscopy. Langmuir 2000, 16, 708-715. [CrossRef]

94. Allen, S.; Chen, X.; Davies, J.; Davies, M.C.; Dawkes, A.C.; Edwards, J.C.; Roberts, C.J.; Sefton, J.; Tendler, S.J.; Williams, P.M. Detection of antigen-antibody binding events with the atomic force microscope. Biochemistry 1997, 36, 7457-7463. [CrossRef] [PubMed]

95. Horton, M.; Charras, G.; Lehenkari, P. Analysis of ligand-receptor interactions in cells by atomic force microscopy. J. Recept. Signal Transduct. 2002, 22, 169-190. [CrossRef] [PubMed]

96. Willemsen, O.H.; Snel, M.M.; Cambi, A.; Greve, J.; De Grooth, B.G.; Figdor, C.G. Biomolecular interactions measured by atomic force microscopy. Biophys. J. 2000, 79, 3267-3281. [CrossRef]

97. Chtcheglova, L.A.; Shubeita, G.T.; Sekatskii, S.K.; Dietler, G. Force spectroscopy with a small dithering of AFM tip: A method of direct and continuous measurement of the spring constant of single molecules and molecular complexes. Biophys. J. 2004, 86, 1177-1184. [CrossRef]

98. Zapotoczny, S.; Auletta, T.; de Jong, M.R.; Schönherr, H.; Huskens, J.; van Veggel, F.C.; Reinhoudt, D.N.; Vancso, G.J. Chain length and concentration dependence of $\beta$-cyclodextrin-ferrocene host-guest complex rupture forces probed by dynamic force spectroscopy. Langmuir 2002, 18, 6988-6994. [CrossRef]

99. Baumgartner, W.; Hinterdorfer, P.; Schindler, H. Data analysis of interaction forces measured with the atomic force microscope. Ultramicroscopy 2000, 82, 85-95. [CrossRef]

100. Allison, D.P.; Hinterdorfer, P.; Han, W. Biomolecular force measurements and the atomic force microscope. Curr. Opin. Biotechnol. 2002, 13, 47-51. [CrossRef]

101. Li, P.-C.; Makarov, D.E. Ubiquitin-like protein domains show high resistance to mechanical unfolding similar to that of the I27 domain in titin: Evidence from simulations. J. Phys. Chem. B 2004, 108, 745-749. [CrossRef]

102. Janovjak, H.; Kessler, M.; Oesterhelt, D.; Gaub, H.; Müller, D.J. Unfolding pathways of native bacteriorhodopsin depend on temperature. EMBO J. 2003, 22, 5220-5229. [CrossRef] [PubMed]

103. Carrion-Vazquez, M.; Oberhauser, A.F.; Fowler, S.B.; Marszalek, P.E.; Broedel, S.E.; Clarke, J.; Fernandez, J.M. Mechanical and chemical unfolding of a single protein: A comparison. Proc. Natl. Acad. Sci. USA 1999, 96, 3694-3699. [CrossRef] [PubMed]

104. Brockwell, D.J.; Paci, E.; Zinober, R.C.; Beddard, G.S.; Olmsted, P.D.; Smith, D.A.; Perham, R.N.; Radford, S.E. Pulling geometry defines the mechanical resistance of a $\beta$-sheet protein. Nat. Struct. Mol. Biol. 2003, 10, 731. [CrossRef] [PubMed]

105. Dufrêne, Y.F.; Martínez-Martín, D.; Medalsy, I.; Alsteens, D.; Müller, D.J. Multiparametric imaging of biological systems by force-distance curve-based AFM. Nat. Methods 2013, 10, 847. [CrossRef] [PubMed]

106. Introduction to Brukers ScanAsyst and PeakForce Tapping Atomic Force Microscopy Technology. Available online: https://www.bruker.com/Introduction_to_Brukers_ScanAsyst_and_PeakForce_Tapping Atomic_Force_Microscopy_Technology_AFM_AN133.pdf (accessed on 22 February 2018).

107. Viani, M.B.; Schäffer, T.E.; Paloczi, G.T.; Pietrasanta, L.I.; Smith, B.L.; Thompson, J.B.; Richter, M.; Rief, M.; Gaub, H.E.; Plaxco, K.W.; Cleland, A.N. Fast imaging and fast force spectroscopy of single biopolymers with a new atomic force microscope designed for small cantilevers. Rev. Sci. Instrum. 1999, 70, 4300-4303. [CrossRef]

108. Kienberger, F.; Ebner, A.; Gruber, H.J.; Hinterdorfer, P. Molecular recognition imaging and force spectroscopy of single biomolecules. Acc. Chem. Res. 2006, 39, 29-36. [CrossRef] [PubMed]

109. Ludwig, M.; Dettmann, W.; Gaub, H.E. Atomic force microscope imaging contrast based on molecular recognition. Biophys. J. 1997, 72, 445-448. [CrossRef]

110. Senapati, S.; Lindsay, S. Recent progress in molecular recognition imaging using atomic force microscopy. Acc. Chem. Res. 2016, 49, 503-510. [CrossRef] [PubMed] 
111. Raab, A.; Han, W.; Badt, D.; Smith-Gill, S.J.; Lindsay, S.M.; Schindler, H.; Hinterdorfer, P. Antibody recognition imaging by force microscopy. Nat. Biotechnol. 1999, 17, 901. [CrossRef] [PubMed]

112. Stroh, C.; Wang, H.; Bash, R.; Ashcroft, B.; Nelson, J.; Gruber, H.; Lohr, D.; Lindsay, S.M.; Hinterdorfer, P. Single-molecule recognition imaging microscopy. Proc. Natl. Acad. Sci. USA 2004, 101, 12503-12507. [CrossRef] [PubMed]

113. Creasey, R.; Sharma, S.; Gibson, C.T.; Craig, J.E.; Ebner, A.; Becker, T.; Hinterdorfer, P.; Voelcker, N.H. Atomic force microscopy-based antibody recognition imaging of proteins in the pathological deposits in Pseudoexfoliation Syndrome. Ultramicroscopy 2011, 111, 1055-1061. [CrossRef] [PubMed]

114. Stroh, C.M.; Ebner, A.; Geretschläger, M.; Freudenthaler, G.; Kienberger, F.; Kamruzzahan, A.S.M.; Smith-Gill, S.J.; Gruber, H.J.; Hinterdorfer, P. Simultaneous topography and recognition imaging using force Microscopy. Biophys. J. 2004, 87, 1981-1990. [CrossRef] [PubMed]

115. Kaur, P.; Fuhrmann, A.; Ros, R.; Kutner, L.O.; Schneeweis, L.A.; Navoa, R.; Steger, K.; Xie, L.; Yonan, C.; Abraham, R.; et al. Antibody-unfolding and metastable-state binding in force spectroscopy and recognition imaging. Biophys. J. 2011, 100, 243-250. [CrossRef] [PubMed]

116. Chtcheglova, L.A.; Wildling, L.; Waschke, J.; Drenckhahn, D.; Hinterdorfer, P. AFM functional imaging on vascular endothelial cells. J. Mol. Recognit. 2010, 23, 589-596. [CrossRef] [PubMed]

117. Xiao, L.; Chen, Q.; Wu, Y.; Qi, X.; Zhou, A. Simultaneous topographic and recognition imaging of epidermal growth factor receptor (EGFR) on single human breast cancer cells. Biochim. Biophys. Acta BBA Biomembr. 2015, 1848, 1988-1995. [CrossRef] [PubMed]

118. Ivanov, Y.D.; Bukharina, N.S.; Pleshakova, T.O.; Frantsuzov, P.A.; Andreeva, E.Y.; Kaysheva, A.L.; Zgoda, V.G.; Izotov, A.A.; Pavlova, T.I.; Ziborov, V.S.; et al. Atomic force microscopy fishing and mass spectrometry identification of gp120 on immobilized aptamers. Int. J. Nanomed. 2014, 9, 4659-4670.

119. Creasey, R.; Sharma, S.; Craig, J.E.; Gibson, C.T.; Ebner, A.; Hinterdorfer, P.; Voelcker, N.H. Detecting protein aggregates on untreated human tissue samples by atomic force microscopy recognition imaging. Biophys. J. 2010, 99, 1660-1667. [CrossRef] [PubMed]

120. Barattin, R.; Voyer, N. Chemical modifications of AFM tips for the study of molecular recognition events. Chem. Commun. 2008, 0, 1513-1532. [CrossRef] [PubMed]

121. Rissin, D.M.; Kan, C.W.; Campbell, T.G.; Howes, S.C.; Fournier, D.R.; Song, L.; Piech, T.; Patel, P.P.; Chang, L.; Rivnak, A.J.; et al. Single-molecule enzyme-linked immunosorbent assay detects serum proteins at subfemtomolar concentrations. Nat. Biotechnol. 2010, 28, 595-599. [CrossRef] [PubMed]

122. Archakov, A.; Ivanov, Y.; Lisitsa, A.; Zgoda, V. Biospecific irreversible fishing coupled with atomic force microscopy for detection of extremely low-abundant proteins. Proteomics 2009, 9, 1326-1343. [CrossRef] [PubMed]

123. Archakov, A.I.; Ivanov, Y.D.; Lisitsa, A.V.; Zgoda, V.G. AFM fishing nanotechnology is the way to reverse the Avogadro number in proteomics. Proteomics 2007, 7, 4-9. [CrossRef] [PubMed]

124. Archakov, A.I.; Ivanov, Y.D. Analytical nanobiotechnology for medicine diagnostics. Mol. Biosyst. 2007, 3, 336-342. [CrossRef] [PubMed]

125. Anderson, N.L. The clinical plasma proteome: A survey of clinical assays for proteins in plasma and serum. Clin. Chem. 2010, 56, 177-185. [CrossRef] [PubMed]

126. Naryzhny, S.N.; Zgoda, V.G.; Maynskova, M.A.; Ronzhina, N.L.; Belyakova, N.V.; Legina, O.K.; Archakov, A.I. Experimental estimation of proteome size for cells and human plasma. Biochem. Mosc. Suppl. Ser. B Biomed. Chem. 2015, 9, 305-311. [CrossRef]

127. Pleshakova, T.O.; Shumov, I.D.; Ivanov, Y.D.; Malsagova, K.A.; Kaysheva, A.L.; Archakov, A.I. AFM-based technologies as the way towards the reverse Avogadro number. Biochem. Mosc. Suppl. Ser. B Biomed. Chem. 2015, 9, 244-257. [CrossRef]

128. Ivanov, A.S.; Medvedev, A.; Ershov, P.; Molnar, A.; Mezentsev, Y.; Yablokov, E.; Kaluzhsky, L.; Gnedenko, O.; Buneeva, O.; Haidukevich, I.; et al. Protein interactomics based on direct molecular fishing on paramagnetic particles: Practical realization and further SPR validation. Proteomics 2014, 14, 2261-2274. [CrossRef] [PubMed]

129. Pleshakova, T.O.; Kaysheva, A.L.; Bayzyanova, J.M.; Anashkina, A.S.; Uchaikin, V.F.; Shumov, I.D.; Ziborov, V.S.; Konev, V.A.; Archakov, A.I.; Ivanov, Y.D. Advantages of aptamers as ligands upon protein detection by AFM-based fishing. Anal. Methods 2017, 9, 6049-6060. [CrossRef] 
130. Kaysheva, A.L.; Ivanov, Y.D.; Zgoda, V.G.; Frantsuzov, P.A.; Pleshakova, T.O.; Krokhin, N.V.; Ziborov, V.S.; Archakov, A.I. Visualization and identification of hepatitis $C$ viral particles by atomic force microscopy combined with MS/MS analysis. Biochem. Mosc. Suppl. Ser. B Biomed. Chem. 2010, 4, 15-24. [CrossRef]

131. Kopylov, A.T.; Zgoda, V.G.; Lisitsa, A.V.; Archakov, A.I. Combined use of irreversible binding and MRM technology for low- and ultralow copy-number protein detection and quantitation. Proteomics 2013, 13, 727-742. [CrossRef] [PubMed]

132. Ivanov, Y.D.; Kaysheva, A.L.; Frantsuzov, P.A.; Pleshakova, T.O.; Krohin, N.V.; Izotov, A.A.; Shumov, I.D.; Uchaikin, V.F.; Konev, V.A.; Ziborov, V.S.; et al. Detection of hepatitis C virus core protein in serum by atomic force microscopy combined with mass spectrometry. Int. J. Nanomed. 2015, 10, 1597-1608.

133. Kaysheva, A.L.; Ivanov, Y.D.; Frantsuzov, P.A.; Krohin, N.V.; Pavlova, T.I.; Uchaikin, V.F.; Konev, V.A.; Kovalev, O.B.; Ziborov, V.S.; Archakov, A.I. Mass spectrometric detection of the amino acid sequence polymorphism of the hepatitis C virus antigen. J. Virol. Methods 2016, 229, 86-90. [CrossRef] [PubMed]

134. Pleshakova, T.O.; Kaysheva, A.L.; Bayzyanova, J.M.; Anashkina, A.S.; Uchaikin, V.F.; Ziborov, V.S.; Konev, V.A.; Archakov, A.I.; Ivanov, Y.D. The detection of hepatitis c virus core antigen using AFM chips with immobolized aptamers. J. Virol. Methods 2018, 251, 99-105. [CrossRef] [PubMed]

135. Nettikadan, S.R.; Johnson, J.C.; Vengasandra, S.G.; Muys, J.; Henderson, E. ViriChip: A solid phase assay for detection and identification of viruses by atomic force microscopy. Nanotechnology 2004, 15, 383. [CrossRef]

136. Huff, J.L.; Lynch, M.P.; Nettikadan, S.; Johnson, J.C.; Vengasandra, S.; Henderson, E. Label-Free Protein and Pathogen Detection Using the Atomic Force Microscope. J. Biomol. Screen. 2004, 9, 491-497. [CrossRef] [PubMed]

137. Shumov, I.D.; Kanashenko, S.L.; Ziborov, V.S.; Ivanov, Y.D.; Archakov, A.I.; Pleshakova, T.O. Formation of sensor array on the AFM chip surface by magnetron sputtering. J. Phys. Conf. Ser. 2017, 789, 012053. [CrossRef]

138. BioScope Resolve Overview/BioAFM Atomic Force MicroscopelBruker. Available online: https:/ / www.bruker.com/ru/products/surface-and-dimensional-analysis/atomic-force-microscopes / bioscope-resolve/overview.html (accessed on 29 March 2018).

139. Wu, J.; Ding, G.; Chen, X.; Han, T.; Li, Y.; Wei, J. Development of a multiprobe instrument for measuring microstructure surface topography. Sens. Actuators Phys. 2017, 263, 363-368. [CrossRef]

140. Khanal, D.; Kondyurin, A.; Hau, H.; Knowles, J.C.; Levinson, O.; Ramzan, I.; Fu, D.; Marcott, C.; Chrzanowski, W. Biospectroscopy of nanodiamond-induced alterations in conformation of intra- and extracellular proteins: A nanoscale IR study. Anal. Chem. 2016, 88, 7530-7538. [CrossRef] [PubMed]

141. Kassies, R.; van der Werf, K.O.; Lenferink, A.; Hunter, C.N.; Olsen, J.D.; Subramaniam, V.; Otto, C. Combined AFM and confocal fluorescence microscope for applications in bio-nanotechnology. J. Microsc. 2005, 217, 109-116. [CrossRef] [PubMed]

(c) 2018 by the authors. Licensee MDPI, Basel, Switzerland. This article is an open access article distributed under the terms and conditions of the Creative Commons Attribution (CC BY) license (http://creativecommons.org/licenses/by/4.0/). 